\title{
Looking for the Impossible: The Futile Search for a Balanced Doctrine of Humanitarian Intervention
}

\author{
Arman Grigoryan, Lehigh University, Bethlehem, USA
}

Correspondence: arg210@lehigh.edu

\begin{abstract}
Many in the West, especially in the human rights community, saw the end of the Cold War as a great opportunity for a normative transformation in international relations. They argued that the concept

of sovereignty was an anachronism and that a new international regime should be created allowing for easier intervention against states that subject their citizens to violence. It seemed like a relatively straightforward issue of clashing normative principles at first. As the conversation about interventions has evolved, however, it has become increasingly clear that the problem is much more complex. This article examines the set of complex trade-offs between various values and norms related to humanitarian intervention and demonstrates that no interventionist doctrine that balances these values and norms is possible. It empirically examines these tensions in the context of interventions in Kosovo and Libya.
\end{abstract}

\section{KEYWORDS}

Humanitarian intervention, Responsibility to Protect, Sovereignty, Treaty of Westphalia, UN authorization, Kosovo, Libya 
Humanitarian intervention is a noble idea and a seemingly simple one. It is rooted in the principle of universal human rights, which insists that all human beings are endowed with basic inalienable rights and that these rights are not constrained by race, gender, age, or citizenship. Violations of human rights, consequently, cannot be treated as a particular country's business. That is why some especially egregious violations are defined as crimes against humanity, not just against the group of people that has been the target of those violations. When such crimes are committed, therefore, the international community should have the right, indeed the obligation, to intervene and to protect the victims.

This normative ideal has not been the empirical reality, of course. Human rights were first explicitly codified and made part of international law in 1948 when the United Nations adopted the Universal Declaration of Human Rights. The adoption of that document, however, temporally coincided with the start of the Cold War. For the subsequent four decades, everything, including human rights, was subordinated to and subsumed by, the logic of the Cold War. More specifically, either human rights were treated as a costly distraction, or they were deployed instrumentally and strategically against the adversary. Thus, the United States accused the Soviet Union and its allies of trampling on the civil rights and freedoms of their societies, while the Soviet Union accused the United States and its allies of neocolonial and racial oppression, support for right-wing dictatorships, and economic exploitation of the poor by the rich.

The end of the Cold War produced a shift in the human rights discourse in the West. It freed up resources that were hitherto reserved for the superpower competition and made tolerating human rights violations for strategic reasons unnecessary. In addition, the immediate aftermath of the Cold War saw an uptick in intrastate warfare, accompanied by appalling instances of civilian victimization. Human rights, accordingly, moved from the margins of the foreign policy discourse to, if not the center, then closer to it, as did the conversation about humanitarian intervention. An army of intellectuals and activists in the West embarked on a mission to remove barriers against such interventions and to design a normative and legal framework, which would guide and regulate their practice in the new era.

Much of the attention initially focused on two problems in particular - the need to convince potential interveners that the costs of intervention to them should not be a deterrent against intervention and that the norm of sovereignty should be redefined as something subordinate to the imperative of protecting human rights. As the conversation about interventions has evolved, however, it has become obvious that the problem is far more complex than merely solving these problems. It entails a set of inescapable trade-offs, and even these two oft-discussed issues - caring for strangers and taking the shield of sovereignty away from human rights violators - are not as simple morally, legally, and politically as they seem at first glance. This article provides an analysis of these trade-offs and attempts to answer the related question of whether a balanced doctrine of humanitarian intervention that simultaneously satisfies a set of desirable criteria is possible at all. Additionally, the article analyzes the two most prominent cases of Western interventions in light of the discussion of those trade-offs - Kosovo and Libya - and provides a brief discussion of cases where the West either looked the other way or took the perpetrator's side. 


\section{The Evolution of the Debate on Humanitarian Interventions}

The first phase of the conversation about humanitarian intervention was effectively dominated by writings that constituted advocacy. Its contributors set out to convince the public in the U.S. and other Western democracies to assume a more activist role in response to human rights violations. Some of the writings in this period were narratives of the horrors committed against innocent people with the world looking the other way. ${ }^{1}$ They were designed to awaken the conscience of the world and to shape a new moral environment, where atrocities could not be ignored. Others put the norm of sovereignty in their crosshairs, arguing that it was a morally questionable norm in urgent need of revision and amendment. ${ }^{2}$

There was pushback against this newfound enthusiasm for interventions almost immediately. Some skeptics argued that the proponents of intervention did not make a good enough case that interveners indeed have an obligation to save strangers if doing so entailed harm to the intervener. M. Mandelbaum famously derided the idea of interventions as confusing foreign policy with social work. ${ }^{3}$ Even before the conversation about intervention had begun attracting attention in Washington, warnings against such activism were issued by libertarians in the U.S., who are typically suspicious of activist foreign policies of any kind as excuses for higher taxes and a bigger government, and who had sensed (correctly) that the end of the Cold War was going to result not in retrenchment, but in the procurement of new missions, including humanitarian interventions. ${ }^{4} \mathrm{Critics}$ also began to point out that intervention is a more complex problem than simply overcoming moral indifference to the suffering of strangers and discarding the norm of sovereignty. R. Betts was one of the first scholars to point this out, arguing specifically, that intervention advocates often do not realize that there is a tension between peace and justice and that interventions cannot be impartial and effective at the same time. ${ }^{5}$

Another set of authors criticized the intervention advocacy literature for its failure to appreciate that interventions involved strategic interaction that might produce unintended consequences. Several of them focused on moral hazards. They argued, specifically, that the promise of intervention might generate perverse incentives, whereby minorities might provoke the very violence that interventions were supposed to protect them from. ${ }^{6}$ Others demonstrated that states targeted for intervention may have incentives to escalate the violence against minorities under certain circumstances. ${ }^{7}$

These criticisms did not defeat the advocacy for humanitarian interventions. They transformed the debate, however, which became more refined and sophisticated. In particular, there was increasing awareness about tensions between various norms that were individually held in high regard. ${ }^{8}$ There were also efforts to reconcile

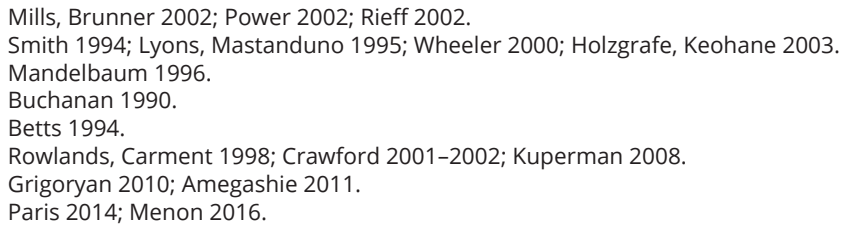


some of them, which culminated in the development and adoption of the doctrine of Responsibility to Protect (R2P) by the United Nations in 2005. The doctrine tried to square two circles in particular - the tension between the concept of sovereignty and the norm of protecting the innocent, and the problem of legitimate authority to sanction interventions. ${ }^{1}$ In the first case it essentially redefined sovereignty as custodianship. In the second, it insisted on international consensus for offering protection. As I argue below, these efforts were ultimately unsuccessful, as have been the efforts to reconcile the other tensions inherent in any possible interventionist doctrine.

\section{Sovereignty vs. Human Rights}

The first problem the proponents of humanitarian intervention had to deal with in the post-Cold War debate was that of sovereignty and the obstacles against intervention inherent in that concept. Sovereignty has traditionally been defined as an exclusive legal and political authority within the boundaries of a state, which precludes any exercise of such authority by other entities in the form of interventions or interference, except when the state itself has granted such authority. This principle, which was first codified in the Treaty of Westphalia in 1648, has certainly not deterred all cases of interference and interventions. Great powers have interfered in the affairs of weaker states or intervened with force routinely. But the advocates of humanitarian intervention in the post-Cold War West were keen on creating a framework that would not only make intervening easier but also make it consistent with international law and liberal norms. As R. Jackson writes: "I am ... interested in knowing not when intervention may be opportune, but, rather, when it may be justified - which is a legal and moral question."2

Intervention advocates put forward a set of normative arguments to that end. One of them was that the concept of sovereignty should be interpreted differently for democracies and non-democracies. Originally, of course, there was no such distinction, nor could there be, since there were no democracies at the time sovereignty emerged as a concept. Modern liberal theorists have argued, nonetheless, that the right to sovereignty is normatively coherent only for democracies. From the liberal perspective, governments are legitimate only if they have the consent of their citizens. If they do not have such consent, they cannot claim to represent legitimately the people they rule, and since it is nations that are sovereign in our age of politics by popular consent, non-democratic governments cannot invoke the right to non-intervention. ${ }^{3}$

Another argument has focused not so much on the regime type but on the definition of sovereignty itself. Traditionally, the concept has been defined as exclusive legal and political authority, which is almost coterminous with the right to non-intervention. Some intervention advocates have argued that it should be redefined as custodianship instead. Specifically, a state has a legitimate right to nonintervention only as long as it protects people in its charge. If it fails in that duty 
because of incapacity or if it commits the violence itself, then that state ceases to be sovereign. Intervention against such a state must be allowed or even required. This logic is at the core of the R2P doctrine, even though the doctrine is quite equivocal on "non-consensual" intervention. ${ }^{1}$

These are normatively appealing, one could even say unassailable, claims. It is certainly not obvious, why a government that does not represents its people should be accorded the same respect and legal protections as governments that do. It is nations that are sovereign after all, not governments. It is even less obvious that a government that murders its people should be protected against foreign intervention because of an undifferentiated commitment to some abstract principle. After all, the initial intent of the concept was never to grant absolute protection to states to do as they please with their subjects. Rather, European states decided that they needed it to combat the disorder and potential for friction resulting from overlapping claims of political and legal authority by different entities over the same territory and population, and to deter external interference in succession struggles in European monarchies. Over time the concept of sovereignty came to be understood more as a normative and a legal shield against exploitation of the weak by the powerful in the international system, which is a perfectly valid normative position designed to make the international system less of a jungle where the strong eat the weak, and more like a society, where relations are supposed to be based on fairness, equality, and protection from predation. That normative position, however, is in no way logically equivalent to granting states a license to do as they please with their citizens. It is logically possible to have a norm protecting states from predation by more powerful states and a norm that protects ordinary citizens against predation by their state simultaneously.

While logically possible, however, such separation is difficult in practice. Relaxing the norm against intervention or introducing a norm of humanitarian intervention that creates exceptions to it increases the risk that the powerful will appeal to those exceptions willy-nilly every time they have a dispute with another, weaker state. The question is whether we can devise instruments that achieve separation and put obstacles on the path of arbitrary interventions at the same time.

\section{What Sort of Persecution Justifies Intervention?}

One possible solution is to reserve the right to intervene only in most egregious cases of violence, which is usually defined operationally as genocides. ${ }^{2}$ The assumption is that when we are witnessing a genocide, ulterior motives would cease to be of concern. The bar for justified intervention would be set very high, and it would not even matter if ulterior motives were present. Unfortunately, this does little to solve the problem.

To begin with, even though genocide seems to be a type of violence that can be easily recognized and distinguished from other types of violence, it is not an easy task in actual reality. Thus, the official legal definition of that crime in the Convention on

2 Walzer 1977; Charles Krauthammer, "Drawing the Line at Genocide," Washington Post, December 11, 1992, accessed September 29, 2021, https://www.washingtonpost.com/archive/opinions/1992/12/11/drawing-the-line-at-genocide/09159898-b9f1-434bb5d7-c0511943d4ce/. 
the Prevention and Punishment of the Crime of Genocide is one of the most amorphous definitions of a concept. It defines genocide as: ${ }^{1}$

"any of the following acts committed with the intent to destroy in whole or in part a national, racial, ethnic group, as such a) killing members of the group; b) causing serious bodily or mental harm to members of the group; c) deliberately inflicting on the group conditions of life calculated to bring about its physical destruction in whole or in part; d) imposing measures to prevent births within the group; e) forcibly transferring children of the group to another group."

Even a cursory glance at the definition reveals that just about any case of civilian victimization can be defined as genocide, yet we know that civilian victimization is sometimes coercive, not exterminationist. It is coercive, rather than exterminationist, most of the time. One could argue, of course, that civilian victimization should be enough to trigger an intervention, and that exterminationist intent should not be a requirement. But then we must decide what level of civilian victimization should be the threshold. Should it be some arbitrary absolute number? Should it be a percentage of the population that is being victimized? Finding agreements on such numbers would be an impossible task.

One solution would be to tighten the definition of genocide and to restrict it to cases of violence where the entire group is targeted for extermination, which also has the advantage of conforming to our common sense understanding of what a genocide is. But this creates a different problem. Because exterminationist and coercive violence may be difficult to distinguish in early stages, a standard insisting on intervention only against genocides defined in this way would mean that interventions would be justified only when they were pointless. Specifically, at the point when we know for sure that what we are witnessing is genocide, there would be nobody left to save. If we erred in the opposite direction, however, we would have too many "false positives" (i.e. cases of low-level violence that were not going to become genocidal), hence too many candidates for intervention, and too many interventions by the powerful against the weak for reasons having nothing to with humanitarian concerns. ${ }^{2}$

\section{More on Purity and Impurity of Motives}

The purity and impurity of motives are related to another important trade-off, which is parallel to what critics have pointed out about the idea of collective security. That idea requires states to subordinate their other interests to the imperative of maintaining peace, confronting revisionist states, and standing by the victims of aggression. This, according to critics, is utopian. States are not going to incur the costs of confronting aggressors for the abstract commitment to peace. States are likely

1 "Convention on the Punishment and Prevention of the Crime of Genocide (1948)," UN, accessed September 21, 2021, https:// www.un.org/en/genocideprevention/documents/atrocity-crimes/Doc.1_Convention\%20on\%20the\%20Prevention\%20and\%20 Punishment\%20of\%20the\%20Crime\%20of\%20Genocide.pdf.

2 Paris 2014. 
to confront aggressors if there is more than a commitment to peace at stake for them. They are also not going to be indifferent to the identities of aggressors and victims. ${ }^{1}$ The same logic applies to humanitarian interventions. States' willingness to intervene is always going to be determined by self-serving interests rather than the concern for human rights. Specifically, the less intense such preferences are, the less likely potential interveners are to intervene. Conversely, the more likely they are to intervene, the more likely interveners are to have impure motives. States are also unlikely to be indifferent to the identities of perpetrators and victims: they will intervene if support for the victim serves the intervener's interests, and are less likely to do so otherwise. In fact, if the interests so demand, they will even protect the perpetrators.

Some have argued that impure motives are not a problem, necessarily. As long as an intervener is willing to rescue a persecuted population, it doesn't matter if it dovetails with their other, non-humanitarian motives. ${ }^{2}$ But this does not address the problem of two or more states having impure motives that are inconsistent with each other. No coherent doctrine can resolve this problem beyond hollow admonitions that states should put the concern for human rights above their strategic and material interests. The argument leaves the problem of the strong taking advantage of the weak unaddressed as well because it does not deal with the problem of "undeserving" or complicated cases being defined as persecution to greenlight an intervention.

Impure motives are problematic for yet another reason. If an intervener's primary motive for intervention is some conflict with the target-state unrelated to the violence it is committing against its domestic opponents, then the intervener might have incentives to sabotage attempts at finding compromise solutions. Such an intervener, in other words, might be willing to risk the continuation of violence against those very domestic opponents of the target-state or even escalation of that violence if it cares about the opportunity to intervene more than about saving the persecuted. ${ }^{3}$

\section{Who Should Intervene?}

One other instrument that could coherently allow for exceptions to the norm of sovereignty is to define as legitimate only interventions that are sanctioned by the UN Security Council as is the case with every other instance of the legitimate use of force except for repelling aggression, or more generally, that they are multilateral. Such a standard may solve a problem, but it inevitably creates others.

To begin with, the requirement for a sanction by the UN Security Council increases the probability of gridlock. As I have pointed out already, it is simply utopian to expect that states will ever put the concern for human rights above their strategic and material interests. They will not be indifferent to the identities of perpetrators and victims. More often than not states are likely to have inconsistent preferences and line up on opposite sides. There are plenty of examples of such behavior in the past. The United States and China were very critical of India when the latter invaded Pakistan in 1971, although that invasion stopped a bloody slaughter of Bengalis by the Pakistani 
army. The U.S. and China were similarly critical of Vietnam's intervention in Cambodia in 1978, although that intervention stopped the horrific mass murder that was being carried out by the Khmer Rouge regime. Russia and China criticized the United States for the intervention in Kosovo and threatened a veto in the UN Security Council if the U.S. requested authorization for the use of force in 1999. In 2008, the United States criticized Russia for the intervention in Georgia. This list can be continued.

Second, when states do agree to act in concert, the mandate and strategy of intervention are likely to reflect not what the problem at hand requires, but whatever bargain participants can strike about its various elements and aspects. To put it differently, strategies of multilateral interventions are likely to be designed not relying on the logic of consequences, but on the logic of appropriateness. And that usually produces suboptimal results. This is not mere speculation. During the intervention in Kosovo, for example, members of the coalition that carried it out had to give explicit consent to various aspects of the intervention, including things like daily confirmation of target maps. The possibility of a ground operation was also taken off the table initially at least in part because some members of the coalition were vehemently opposed to it. Consequently, the strategy and the conduct of the intervention were shaped more by political considerations than by what was necessary for success militarily. ${ }^{1}$

The insistence on multilateralism is in tension with how rapidly an intervention can be carried out as well. As the Rwandan genocide has starkly and chillingly demonstrated, mass murder can be carried out very rapidly. The whole campaign in Rwanda lasted less than two months. Half of the victims of that genocide were murdered in the first two weeks after the commencement of the campaign. Any deliberation for an intervention in a multilateral body like the UN is going to take time. By the time they have hammered out an agreement to intervene, and negotiated over its tactical and logistical details, too many people will be dead.

It is not obvious what the solution to this problem is, however. If we were to relax the demand for multilateralism and a UN sanction because it takes too much time and it has the potential of producing suboptimal strategies, then who should be granted the license to intervene? Great powers? Neighbors? Whoever can? Unfortunately, positive answers to any of these questions are vulnerable to the counterargument that risks of exploitative, arbitrary interventions will go up.

\section{Other Trade-Offs}

The trade-offs related to the tension between human rights and state sovereignty are not the only ones making the prospects of devising a balanced doctrine of humanitarian intervention dim. Several others make the problem even more complicated.

As I mentioned earlier, one of the missions intervention advocates took up in the period immediately following the end of the Cold War was convincing potential interveners that saving strangers was a noble cause. They argued that selfish disregard for the fate of innocent people on the grounds that they are not fellow citizens could 
have no moral justification. These arguments, however, often did not go beyond general admonitions and failed to deal with certain controversies inherent in the position.

To begin with, it is not a morally uncontroversial demand to help someone if doing so can harm the helper. Humanitarian interventions are not merely a matter of being generous and compassionate to strangers. Compassion in this case can risk the lives of your soldiers, and it is not clear that putting the lives of your soldiers at risk to save the lives of foreigners is a morally uncontroversial choice. If we think of this problem not in terms of a simple dichotomous choice between intervening or not, but rather in terms of making the decision to intervene a continuous function of potential costs, we have another problem, which is that interventions by the powerful against the weak will be morally less controversial than interventions against powerful target-states that can impose serious costs against the intervener. What makes it more interesting is that such a moral attitude can be derived from the "just war theory," which among other things insists that military action can be justified only if it has a reasonable chance of success and when it does more good than harm. ${ }^{1}$ Something is unsettling about this. It amounts to endorsing the morality of selective justice.

The issue of costs is problematic for another reason. If an intervener decides to intervene but tries simultaneously to ensure that the costs of intervention are as low as possible, it might make strategic choices that are less than optimal from the perspective of saving the lives of the persecuted. For example, the intervener might choose to rely on airstrikes as the method of coercion, rather than a ground invasion. Such a strategic choice will impose costs on the intervener without necessarily making it impossible to continue or escalate the violence against the beneficiaries of intervention, which targets of intervention may have incentives to do. ${ }^{2}$

\section{After the Rescue}

The intervention advocacy literature is focused overwhelmingly on the problem of halting or preventing persecution. Rarely, if ever, contributors to this literature concern themselves with the problem of the aftermath. Specifically, this literature often fails to consider the question of what happens after the violence is halted. This is not something that can be dismissed as irrelevant or outside of the scope of this literature, for interveners will have to leave eventually. Consequently, they must make sure also that the order they leave behind ensures stable peace. Unfortunately, that task is subject to a difficult trade-off as well.

Any post-violence political order is going to be grounded in one of two basic logics: either the victims should be reintegrated into the state that has been subjecting them to violence or that state should be partitioned with victims allowed to create their own state. While not impossible in principle, successful reconciliation and reintegration seem like an extraordinarily difficult task. A population that has been subjected to large-scale violence is going to have difficulties trusting a state that has committed that violence. The logic, in fact, seems bizarre. If we were to accept the definition of sovereignty as custodianship, a state that has been murdering people under its custodianship, has already lost the right to represent, 
let alone, govern them. Partitioning such a state seems eminently reasonable. Indeed, it is difficult to make a liberal argument against secession even if the seceding population has not been subjected to violence. To be sure, there can be all kinds of pragmatic objections to the idea of secession on-demand, some of them quite reasonable. None of them, however, invalidates the claim that liberal theory implies endorsement of secession in principle, because self-determination, i.e. the right of a population to decide how and by whom it is governed, is one of the indispensable pillars of that theory. ${ }^{1}$ The argument that once violence has taken place, separation is the only real option is even easier to make both from a liberal and a pragmatic point of view. ${ }^{2}$

The key argument against this perspective is based on the logic of moral hazard. Specifically, some have insisted that a doctrine that envisions support for separation in case of violence against minorities, might create perverse incentives for them to rebel and to invite violence upon themselves. ${ }^{3}$ Indeed, even without support for secession, a robust international regime of intervention in case of violence against minorities is feared to generate a moral hazard. ${ }^{4}$

The problem with this argument is that its proponents do not propose any superior alternatives. In fact, a firm commitment to non-intervention and opposition to the partition will create perverse incentives as well. Specifically, a state that has no fear that it will face a third-party intervention in case it persecutes a minority or that the international community will endorse separation, might feel less restrained about what it can and cannot do against a restless minority.

It must also be pointed out that interveners have typically dealt with this problem in an ad hoc, selective manner. When they have opposed separation, they have invoked the argument about the inviolability of borders. When they have been inclined to support partition, they have come up with some exception or invented new doctrines, like remedial secession, which they have invoked selectively. ${ }^{5}$

\section{The Empirical Picture}

There have been a handful of Western interventions in the post-Cold War period, including the intervention in Somalia, and the no-fly zones over Bosnia and Iraq. Two interventions, however - Kosovo in 1999 and Libya in 2011 - have been particularly important for two reasons. First, they have been different in intensity and ambition. Second, intervention advocates have hailed both interventions as resounding successes and blueprints to follow in the future. In what follows I examine these two interventions in light of the analysis presented above. I also briefly discuss cases of non-intervention in certain humanitarian crises and cases where the West took the perpetrator's side.

\section{Kosovo}

The intervention in Kosovo was seen by some as a turning point and a harbinger of a new era, where the international community would subordinate strategic and 
material considerations to the moral imperative of saving the innocent, and when it could successfully prevent mass murder or ethnic cleansing. ${ }^{1}$ It was, in fact, the perfect demonstration of practically all the problems described in the preceding pages.

The conflict in Kosovo was a typical secessionist conflict, not unlike several others that erupted in Yugoslavia and the Soviet Union in the late 1980s. Kosovo Albanians had been demanding a status outside of Serbia during the Yugoslav period, and outright independence when Yugoslavia began disintegrating. Serbia resisted and succeeded in suppressing the demand in the early 1990s. Kosovo Albanians themselves initially adopted a strategy of non-violent resistance. After the Dayton Accords, however, Kosovars felt that their strategy of non-violence was a dead-end and that armed resistance had a better chance of success. The Kosovo Liberation Army (KLA) emerged around that time and launched an insurgency. The initial reaction of the U.S. and its NATO allies was critical of the KLA and even tolerant of the Serbian counterinsurgency operations. Sometime in the Fall of 1998, however, the U.S. made a sharp turn in its policy and began turning the screws on Serbia. Specifically, it threatened air strikes if Serbs did not halt their counterinsurgency campaign and withdraw their forces from Kosovo. Serbs complied but extracted a promise from the U.S. and other mediators that the KLA should be prevented from returning to the areas of Serbian withdrawal.

As soon as Serbs withdrew, the KLA violated the terms of the agreement and killed several Serbian civilians. Serbs resumed their counterinsurgency campaign. During one operation on January 23, 1999, a couple of dozen civilians lost their lives in a crossfire in a town called Racak, which set off the crisis that eventually led to the intervention. This incident attracted a tremendous amount of attention. The U.S. leadership concluded, or rather insisted publicly, that it was a signal of Serbian intent to ethnically cleanse or murder the entire Albanian population of Kosovo. Soon thereafter an international conference was convened in Rambouillet, France, during which Serbia was presented with an ultimatum. There were two particularly important paragraphs in it. The first had to do with the status of Kosovo: ${ }^{2}$

"Three years after the entry into force of this agreement, an international meeting shall be convened to determine a mechanism for a final settlement for Kosovo, on the basis of the will of the people, opinions of relevant authorities, each party's efforts regarding implementation of this Agreement and the Helsinki Final Act, and to undertake a comprehensive assessment of the implementation of this agreement and to consider proposals by any party for additional measures."

This was essentially a roadmap for Kosovo's independence. Even more radical was the following paragraph in the military annex of the document: ${ }^{3}$ 
"NATO personnel shall enjoy, together with their vehicles, vessels, aircraft and equipment, free and unrestricted access throughout the FRY [Federal Republic of Yugoslavia] including associated airspace and territorial waters. This shall include, but not be limited to the right to bivouac, maneuver, billet, and utilization of any areas or facilities as required for support, training, and operations."

This was essentially a demand that Serbs relinquish their sovereign statehood, which they rejected. Shortly thereafter, on March 24, NATO launched a campaign of airstrikes, which provoked a Serbian retaliation against the Kosovo Albanian population in the form of forcing them to flee en masse. After five weeks of airstrikes, a ceasefire was announced, which was mediated by Russia, and NATO stationed troops in Kosovo. In 2008 Kosovo declared independence, which was recognized by the U.S. immediately, followed by recognition by a couple of dozen states.

Let us now evaluate this intervention, which many considered a good blueprint to follow the future. First, the evidence suggests that the United States was more interested in destroying the Milosevic government and subduing Serbia than the fate of Kosovo Albanians. It seemed to look for an opportunity to intervene in Kosovo rather than reluctantly doing so to halt a murder campaign. What evidence am I referring to? There was the decision to increase the pressure on Serbia in the Fall of 1998 when a ceasefire had been instituted, the KLA sidelined, and negotiations resumed between the Serbian government and the more moderate Kosovars. The negotiations in question were killed, and a new spiral of violence was triggered in Kosovo because of that pressure. Then there was the ultimatum at Rambouillet, which was designed to be rejected and to give NATO a casus belli. This is not an interpretation of U.S. motives based on the steps it took. People directly involved in the negotiations made statements to that effect. ${ }^{1}$

Second, this case demonstrates how a determined intervener can play fast and loose with definitions. Specifically, the Racak event was deemed sufficient to claim that what was taking place in Kosovo was genocide or ethnic cleansing in progress, which needed to be stopped. ${ }^{2}$ In this regard, it is also worth noting that much bloodier events were taking place at the time in Sierra Lione and Sri Lanka, but they barely attracted any attention in the West.

Third, even though the U.S. and its allies were intent on intervening, they were reluctant to incur serious costs for it. The public opinion in most NATO countries was firmly opposed to a costly intervention. They were certainly opposed to an intervention

1 Jamie Rubin, who was an assistant secretary state at that time, told the Financial Times that Albanian rejection of the deal would be the only failure at Rambouillet, i.e. Serbian rejection would not be a failure. See James Rubin, "The Promise of Freedom," Financial Times, October 17, 2000.

2 The U.S. leadership did not honestly think they were dealing with a case of impending genocide or ethnic cleansing. There is smoking-gun evidence for it. Following the Serbian escalation in response to the airstrikes a journalist asked the commander of NATO forces conducting the intervention General Wesley Clark why the coalition had not prepared for such a scenario. This was Clark's response: "We thought the Serbs were preparing for a Spring offensive that would target KLA strongholds, which had been reinforced in the previous months. But we never thought Serbs would push ahead with the wholesale deportation of the ethnic Albanian population." See Jeffrey R. Smith and William Drozdiak, "Serbs' Offensive Was Meticulously Planned," Washington Post, April 11, 1999, accessed September 21, 2021, https://www.washingtonpost.com/archive/politics/1999/04/11/ serbs-offensive-was-meticulously-planned/0b70e691-8155-40b0-8404-acf16039e6f5/. 
that threatened to kill large numbers of their servicemen. Intervention on the cheap, however, increased the risks that Serbs would escalate against Kosovo Albanians: it simultaneously provided them with such an incentive, because that was just about the only thing that they could do to put pressure on the interveners, hoping also to present the interveners and Kosovars alike with a fait accompli, while at the same time failing to tie their hands against such behavior.

Fourth, even though the intervention was multilateral, it was not sufficiently so. More specifically, it was conducted by NATO without the authorization of the body that could have granted a legal license for the intervention - the UN Security Council because Russia and China had threatened to veto any such proposal. Fifth, even in its limited form, the multilateral nature of the intervention affected the strategy and the conduct of intervention in ways that made it less effective. I have already referred to the fact that the operational details of the campaign had to be approved in all NATO capitals daily, which made operational decisions overly dependent on political considerations. Moreover, the ground option was removed from consideration at the start of the intervention to maximize the chances of all coalition members consenting to the intervention.

Sixth, the outcome was far from a simple moral story of the rescue of the persecuted. It was a selective application of some newly invented principle - remedial secession which could have been more justifiably invoked in other cases but was not. It should be mentioned in addition, that many Serbs fled Kosovo after the guns fell silent, fearing retaliation. Nothing was done to stop that.

In sum, the intervention in Kosovo was hardly the right blueprint for dealing with similar problems in the future as some thought at the time. It was, in fact, the perfect demonstration of all the trade-offs and problems discussed above.

\section{Libya}

The NATO intervention in Libya is the second Western intervention that has been hailed as a successful rescue of a persecuted population and the first that was conducted after the U.S. adoption of the R2P doctrine. As I. Daalder and J. Stavridis wrote shortly after the intervention, "NATO's operation in Libya has rightly been hailed as a model intervention. The alliance responded rapidly to a deteriorating situation that threatened hundreds of thousands of civilians rebelling against an oppressive regime. It succeeded in protecting those civilians." ${ }^{\prime 1}$ This triumphalist assessment is far from being accurate. The intervention in Libya was accompanied by the same problems that plagued the intervention in Kosovo.

According to the standard narrative, the conflict in Libya began as a result of the contagion effect generated by the Arab Spring. In February 2011, shortly after the successful and mostly peaceful uprisings in Tunisia and Egypt, people in Libya also rose up in peaceful protests. The largely peaceful protests of the opposition were met with brutal force by the regime of Colonel M. Gaddafi. It was only after this crackdown that the opposition took up arms, which then led to a massive offensive by M. Gaddafi and more indiscriminate use of force. M. Gaddafi succeeded in pushing back the rebels 
to their stronghold Benghazi. There was a real threat of massive casualties if M. Gaddafi were to storm the city. On March 17, 2011, the UN Security Council adopted a resolution instituting a no-fly zone in Libya. The protection accorded by the no-fly zone allowed the rebels to push back M. Gaddafi's forces, eventually killing M. Gaddafi himself, and prevented a large-scale mass murder of civilians.

Just about every element of this narrative is false or a serious distortion. ${ }^{1}$ First, M. Gaddafi did not initiate the violence, the opposition did. M. Gaddafi's forces used non-lethal means to disperse protesters in Benghazi when protests began. But the protests soon turned violent in Benghazi and elsewhere. M. Gaddafi's forces were largely acting in response. Moreover, there is no evidence that they were deliberately targeting civilians, contrary to reports in the Western media. Second, the U.S. and its NATO allies succeeded in obtaining UN authorization for enforcing a no-fly zone but violated their mandate by attacking M. Gaddafi's forces on the ground and essentially serving as the rebels' air force. This became a source of acrimony and tensions between NATO and Russia. Third, not only was there no evidence that M. Gaddafi's forces were deliberately targeting civilians, but there was also no credible reason to believe that he was planning any such atrocities, yet NATO's justification for the intervention was to thwart precisely such escalation. Fourth, it is difficult to claim with a high degree of confidence what motivated NATO's intervention initially, but it is clear that at some point overthrowing M. Gaddafi's regime became the primary goal of the intervention. As A. Kuperman writes, "if NATO had prioritized the protection of civilians, in accordance with its authorization, the transatlantic alliance would have enforced the no-fly zone, bombed forces that were threatening civilians, and attempted to forge a ceasefire. Instead, NATO took actions that were unnecessary or inconsistent with protecting civilians, but which fostered regime change."2

Fifth, and finally, NATO apparently gave no thought as to what would replace Gaddafi's regime once the latter was removed and ended up leaving behind a failed state. It is not a question one can answer conclusively, for no counterfactual questions lend themselves to such answers, but the fact that such a question can be entertained is interesting in and of itself: is it possible that the failure of the Libyan state in the wake of the intervention has resulted in more bloodshed and human suffering than we would have witnessed if Gaddafi and his opponents were allowed to fight it out without any external intervention?

\section{Examples of Non-Intervention and Interventions to Protect the "Wrong" Side}

The skepticism regarding the possibility of devising a balanced and coherent interventionist doctrine and creating a credible international regime that rests on that doctrine is further strengthened by cases, where Western states, which have been the most active promoters of such a doctrine and such a regime, have either turned a blind eye or taken the side of the state committing violence against civilians. The most egregious and famous case, where the West and the world, in general, did nothing to 
stop an extraordinarily violent campaign of mass murder was the genocide in Rwanda. A. Kuperman may be right that the pace of that genocide was so intense that not too many lives would have been saved if there was an intervention. ${ }^{1}$ There is little doubt, however, that that was not the reason why no intervention took place. No major power showed any interest in intervening because none had any material or strategic stake in the outcome of that bloodbath. The same can be said about the persecution of the Rohingya Muslims in Myanmar, or the protracted violence in Congo, or Darfur.

Even more interestingly, Western states have on occasion taken the side of states that have been targeting civilians when their interests have so demanded. Of course, the rhetoric in these cases has been different - states have been targeting terrorists, extremists, and separatists, protecting their sovereignty against "bad" third parties that have been encouraging the said terrorists, extremists, and separatists. In 2008, for example, when Georgia's M. Saakashvili ordered an attack on South Ossetia, which was accompanied by indiscriminate shelling of residential areas of Tskhinvali, the Western reaction was not one of condemnation of $\mathrm{M}$. Saakashvili and his government. It was expressions of support for a country that was defending its territorial integrity, and condemnations of Russia for intervening to dislodge M. Saakashvili from South Ossetia. While the U.S. and its allies were defending the protesters and rebels of the Arab Spring in Libya, they were simultaneously lending support to the government of Bahrain, which was an ally, and which was brutally suppressing the Arab Spring protesters in that country. One of the most appalling human tragedies in recent years has been unfolding in Yemen, where the Houtis are being brutalized by Saudi Arabia. Much of that brutalization is taking place with the help of U.S.-supplied weaponry. This is only a small sample of a much larger population of cases.

\section{Conclusion}

For almost thirty years now a dedicated group of activists, politicians, and journalists in the West has been trying to create a coherent and balanced doctrine, which would transform international law, international norms, and international politics in a way to make the persecution of innocent civilians impossible. They have argued that a kind of strict interpretation of sovereignty, which prohibits any outside interference or intervention in the affairs of the state, is an anachronism. They have argued that demanding absolute respect for the right of non-intervention, even when a government is murdering its citizens, is a misguided interpretation of the intent of the concept of sovereignty. They have argued, therefore, that the right should be revoked in such cases and also called on states to assume a higher level of willingness to incur costs to save strangers. I have argued, however, that a shift in that direction inevitably generates problems of its own. I have argued in addition that no doctrine is possible in principle that would reconcile a set of criteria that are independently desirable. There are inescapable trade-offs between these criteria. The empirical record of the last three decades, meanwhile, has done nothing to undermine that argument. 


\section{СПИСОК ЛИТЕРАТУРЫ / REFERENCES}

Amegashie, J. Atsu. “On Third-Party Interventions in Conflicts: An Economist's View." Peace Economics, Peace Science, and Public Policy 16, no. 2 (April 2011): 1-10. https://doi.org/10.2202/1554-8597.1225.

Auerswald, Phillip E., and David P. Auerswald, eds. The Kosovo Conflict: A Diplomatic History Through Documents. Cambridge, UK: Kluwer Law International, 2000.

Bellamy, Alex. "The Responsibility to Protect and the Problem of Military Intervention." International Affairs 84, no. 4 (July, 2008): 615-639.

Betts, Richard K. "Systems of Peace or Causes of War? Collective Security, Arms Control, and the New Europe." International Security 17, no. 1 (Summer, 1992): 5-43. https://doi.org/10.2307/2539157.

Betts, Richard K. "The Delusion of Impartial Intervention." Foreign Affairs 73, no. 6 (November/ December, 1994): 20-33.

Buchanan, Patrick J. "America First - and Second, and Third." The National Interest, no. 19 (Spring, 1990): 77-82.

Clark, Wesley K. Waging Modern War. NY: Public Affairs, 2002.

Crawford, Timothy W. "Pivotal Deterrence and the Kosovo War: Why the Hollbrooke Agreement Failed." Political Science Quarterly 116, no. 4 (Winter 2001-2002): 499-523. https://doi.org/10.2307/798219.

Crawford, Timothy W., and Alan J. Kuperman, eds. Gambling on Humanitarian Intervention: Moral Hazard, Rebellion and Civil War. London, UK: Routledge, 2008.

Cohen, Roberta. Human Rights Protection for Internally Displaced Persons. Washington, DC: Refugee Policy Group, 1991.

Cole, Darrell. "St. Thomas Aquinas on Virtuous Warfare." Journal of Religious Ethics 27, no. 1 (Spring, 1999): 57-80.

Daalder, Ivo D., and Jamas G. Stavridis. "NATO's Victory in Libya: The Right Way to Run an Intervention," Foreign Affairs 91, no. 2 (March/April, 2012): 2-7.

Deng, Francis M., Sadikiel Kimaro, Terrence Lyons, Donald Rothchild, and I. William Zartman. Sovereignty as Responsibility: Conflict Management in Africa. Washington, DC: The Brookings Institution, 1996.

Fearon, James D. "Separatist Wars, Partition, and World Order." Security Studies 13, no. 4 (Summer 2004): 394-415. https://doi.org/10.1080/09636410490945965.

Getachew, Adom. Worldmaking after Empire: The Rise and Fall of Self-Determination. Princeton, NJ: Princeton University Press, 2020.

Ginsburg, Tom. "How Authoritarians Use International Law." Journal of Democracy 31, no. 4 (October, 2020): 44-58.

Grigoryan, Arman. "Third-Party Intervention and the Escalation of State-Minority Conflicts." International Studies Quarterly 54, no. 4 (December, 2010): 1143-1174.

Holzgrafe, J. L., and Robert Keohane, eds. Humanitarian Intervention: Ethical, Legal, and Political Dilemmas. Cambridge, UK: Cambridge University Press, 2003.

Jackson, Robert H. "International Community beyond the Cold War." In Beyond Westphalia? State Sovereignty and International Intervention, edited by Gene Lyons and Michael Mastanduno, 59-87. Baltimore, MD: Johns Hopkins University Press, 1995.

Kaufmann, Chaim. "Possible and Impossible Solutions to Ethnic Civil Wars." International Security
20, no. 4 (Summer, 1996): 136-175. https://doi. org/10.2307/2539045.

Kuperman, Alan J. The Limits of Humanitarian Intervention: Genocide in Rwanda. Washington, DC: Brookings Institution Press, 2001.

Kuperman, Alan J. "The Moral Hazard of Humanitarian Intervention: Lessons from the Balkans." International Studies Quarterly 52, no. 1 (March 2008): 49-80.

Kuperman, Alan J. "A Model Humanitarian Intervention? Reassessing NATO's Libya Campaign." International Security 38, no. 1 (Summer 2013): 105-136.

Kydd, Andrew H. "Taxing Atrocities or Subsidizing Rebels: Humanitarian Intervention to Save Civilian Lives." Simon-Skjodt Center for the Prevention of Genocide Series of Occasional Papers, no. 4 (2017). https://www. ushmm.org/m/pdfs/Kydd-Game-Theory.pdf.

Langan, John. "The Elements of St. Augustine's Just War Theory." Journal of Religious Ethics 12, no. 1 (Spring, 1984): 19-38.

Lyons, Gene M., and Michael Mastanduno, eds. Beyond Westphalia? State Sovereignty and International Intervention. Baltimore, MD: Johns Hopkins University Press, 1995.

Mandelbaum, Michael. "Foreign Policy as Social Work." Foreign Affairs 75, no. 1 (January/February 1996): 16-32.

Manela, Erez. The Wilsonian Moment: SelfDetermination and the International Origins of Anticolonial Nationalism. Oxford, UK: Oxford University Press, 2009.

Mearsheimer, John J. "The False Promise of International Institutions." International Security 19, no. 3 (Winter 1993-1994): 5-49. https://doi. org/10.2307/2539078.

Menon, Rajan. The Conceit of Humanitarian Intervention. Oxford, UK: Oxford University Press, 2016.

Mills, Nicolaus, and Kira Brunner, eds. The New Killing Fields. NY: Basic Books, 2002.

Paris, Roland. “The 'Responsibility to Protect' and the Structural Problems of Preventive Humanitarian Intervention." International Peacekeeping 21, no. 5 (October, 2014): 574-575. https://doi.org/10.1080/13533 312.2014.963322.

Power, Samantha. 'A Problem from Hell:' America and the Age of Genocide. NY: Basic Books, 2002.

Rieff, David. A Bed for the Night: Humanitarianism in Crisis. NY: Simon and Schuster, 2002.

Rowlands, Dane, and David Carment. "Moral Hazard and Conflict Intervention." In The Political Economy of War and Peace, edited by Murray Wolfson, 267-285. Boston, MA: Kluwer Academic Publishers, 1998. https://doi. org/10.1007/978-1-4615-4961-1_12.

Smith, Tony. "In Defense of Interventions." Foreign Affairs 73, no. 6 (November/December, 1994): 34-46.

Vidmar, Jure. "Remedial Secessions in International Law: Theory and (Lack of) Practice." St. Antony's International Review 6, no. 1 (May, 2010).

Walzer, Michael. Just and Unjust Wars: A Moral Argument with Historical Illustrations, Second Edition. NY: Basic Books, 1977.

Wheeler, Nicholas J. Saving Strangers: Humanitarian Intervention in International Society. Oxford, UK: Oxford University Press, 2000. 


\title{
Author
}

Arman Grigoryan,

Associate Professor at International Relations Department, Lehigh University, 27 Memorial Dr W, Bethlehem, PA 18015, USA.

e-mail: arg210@lehigh.edu

\section{Additional information}

Received: July 7, 2021. Revised: August 16, 2021. Accepted: September 20, 2021.

\section{Disclosure statement}

No potential conflict of interest was reported by the author.

For citation

Grigoryan, Arman. "Looking for the Impossible: the Futile Search for a Balanced Doctrine of Humanitarian Intervention." Journal of International Analytics 12, no. 3 (2021): 105-122.

https://doi.org/10.46272/2587-8476-2021-12-3-105-122

\section{Стремясь к невозможному: тщетные поиски сбалансированной доктрины гуманитарной интервенции}

\begin{abstract}
АННОТАЦИЯ
Многие западные специалисты, особенно те, чья деятельность связана с правами человека, увидели в конце холодной войны прекрасную возможность для нормативной трансформации в международных отношениях. Они доказывали, что концепция суверенитета - анахронизм и что новый международный режим следует сформировать таким образом, чтобы можно было легко проводить интервенции в отношении государств, подвергающих своих граждан насилию. Изначально казалось, что сутью данного вопроса являлось прямое столкновение нормативных принципов. И хотя дебаты касательно интервенций продвинулись в своем развитии, на данный момент стало абсолютно очевидно, что эта проблема гораздо более комплексная. В данной статье рассматривается ряд сложных уступок в сфере ценностей и норм, связанных с гуманитарной интервенцией. Автор эмпирическим путем исследует эти проблемы в контексте интервенций в Республике Косово и Ливии и приходит к выводу, что создание доктрины интервенции, которая могла бы установить баланс между нормами и ценностями, не представляется возможным.
\end{abstract}

\section{КЛЮЧЕВЫЕ СЛОВА}

гуманитарная интервенция, ответственность по защите, суверенитет, Вестфальский мир, санкция ООН, Косово, Ливия

\section{Сведения об авторе}

Арман Самсонович Григорян, доцент Кафедры международных отношений, Лехайский университет, США, PA 18015, Пенсильвания, Бетлехем, Memorial Dr W, 27.

e-mail: arg210@lehigh.edu

\section{Дополнительная информация}

Поступила в редакцию: 7 июля 2021.

Переработана: 16 августа 2021.

Принята к публикации: 20 сентября 2021. 


\section{Конфликт интересов}

Автор заявляет об отсутствии потенциального конфликта интересов.

\section{Цитирование}

Григорян, А.С. Стремясь к невозможному: тщетные поиски сбалансированной доктрины гуманитарной интервенции // Международная аналитика. - 2021. - Том 12 (3). - С. 105-122. https://doi.org/10.46272/2587-8476-2021-12-3-105-122 